\title{
KARAKTERISTIK MIE MERAH GLUTEN FREE DARI TEPUNG GADUNG (Dioscorea hispida Dennst) DAN TEPUNG MOCAF DENGAN PENAMBAHAN GLISEROL
}

\author{
Sri Winarti ${ }^{1)}$, Murtiningsih ${ }^{1)}$ dan Febi Diningtyas Listyawati ${ }^{2)}$ \\ 1) Dosen Program Studi Teknologi Pangan, FTI, UPN “Veteran” Jawa Timur \\ 2) Mahasiswa Program Studi Teknologi Pangan, FTI, UPN “Veteran” Jawa Timur \\ E-mail: winarti.sriwing@gmail.com
}

\begin{abstract}
ABSTRAK
Mie gluten free merupakan mie yang dibuat dari tepung selain terigu yang baik bagi anak penyandang autis. Gadung dan mocaf memiliki kandungan pati yang tinggi sehingga baik dikembangkan untuk produk mie bebas gluten. Salah satu upaya untuk memperbaiki karakteristik mie gadung-mocaf yaitu dengan penambahan gliserol sebagai plasticizer (pemlastis). Selain itu, guna memperbaiki tampilan mie dilakukan penambahan sebagai pewarna alami. Penelitian ini bertujuan untuk mengetahui kombinasi perlakuan terbaik antara tepung gadung-mocaf dan penambahan gliserol untuk menghasilkan mie yang disukai konsumen. Penelitian ini menggunakan Rancangan Acak Lengkap (RAL) pola faktorial dengan 2 faktor yaitu proporsi tepung (gadung:mocaf) (80\%:20\%; 70\%:30\%; 60\%:40\%) dan penambahan gliserol (1\%; $2 \% ; 3 \%)$. Data-data yang diperoleh dianalisis menggunakan analisa ragam, bila terdapat perbedaan nyata dilakukan uji duncan (DMRT).

Hasil penelitian menunjukkan bahwa perlakuan terbaik adalah proporsi tepung gadung: tepung mocaf 6o\%:40\% dan penambahan gliserol 1\%, yang menghasilkan mie kering dengan karakteristik kadar air 7,20\%; kadar abu 1,49\%; kadar pati 68,59\%; kadar amilosa 12,55\%; daya patah 10,44\%; daya rehidrasi 118,89\%; cooking loss 2,85\%; dan elastisitas 29,24\%. Hasil uji sensoris adalah nilai rata-rata warna 3,90 (agak suka); rasa 3,75 (agak suka); tekstur 3,70 (agak suka); dan aroma 3,6o (agak suka). Hasil perlakuan terbaik dianalisa kadar protein adalah 3,02\%, warna L 48,6; a*24,4; b*14,2 dan aktivitas antioksidan 385,00 (mg/ml).
\end{abstract}

Kata kunci : mie kering, tepung gadung, tepung mocaf, gliserol.

\section{PENDAHULUAN}

Mie kering adalah mie segar yang dikeringkan hingga kadar airnya mencapai 8-10\%. Pengeringan pada umumnya dilakukan di bawah sinar matahari atau dengan alat pengering. Mie kering mempunyai kadar air rendah sehingga daya simpannya relatif lama dan mudah penanganannya. Bahan baku pembuatan mie di Indonesia adalah tepung terigu (Astawan, 2008). Sebagai upaya diversifikasi mie dapat disubstitusi atau digantikan dengan tepung umbi-umbian.

Umbi-umbian tinggi kalori merupakan salah satu alternatif yang dapat digunakan sebagai makanan pokok yang bebas gluten misalnya singkong dan gadung. Oleh karena itu, dimanfaatkannya tepung gadung dan tepung mocaf dalam pembuatan mie bebas gluten yang baik untuk penderita autis.
Umbi gadung dapat dimanfaatkan sebagai bahan pangan, namun karena gadung mengandung racun seperti dioscorin dan $\mathrm{HCN}$ maka gadung masih belum terlalu banyak dikonsumsi. Umumnya gadung mengandung HCN sebesar 469,50 ppm (Harijono dkk, 2008); 425,44 Ppm (Sasongko, 2009); dan 362,00 (Syafi'I $\mathrm{dkk}$, 2009). Tubuh manusia dapat menerima $\mathrm{HCN}$ jika mengkonsumsi dalam batas yang ditoleril FAO dalam Harijono dkk, (2008) untuk umbi-umbian dengan kadar $\leq 50 \mathrm{mg} / \mathrm{Kg}$ (berat badan), oleh karena itu gadung harus diolah untuk mengurangi kandungan sianidanya.

Modified cassava flour (MOCAF) adalah produk turunan dari tepung singkong yang menggunakan prinsip modifikasi sel singkong secara fermentasi, dimana mikrobia BAL (Bakteri Asam Laktat) mendominasi selama fermentasi tepung singkong ini (Subagio, 
2007). Tepung gadung maupun tepung MOCAF memiliki karakteristik yang berbeda jika dibandingkan dengan tepung terigu, oleh sebab itu perlu dilakukan perubahan karakteristik tepung jika akan diolah menjadi mie. Tepung mocaf memiliki sifat fisik yang paling mendekati tepung terigu sehingga dapat digunakan untuk membuat mie bebas gluten (Yeni, 2012). Mocaf memiliki kadar pati tinggi kurang lebih 87,3\%, sedangkan kadar pati tepung terigu sekitar $77,3 \%$ (Nio, 2012). Mocaf memiliki warna yang lebih putih dibandingkan dengan tepung terigu (Salim, 2011).

Tepung gadung dan tepung mocaf tidak bisa dibuat adonan yang selanjutnya dibentuk menjadi lembaran mie. Penambahan tepung gadung dan tepung mocaf pada pembuatan mie menyebabkan kurang elastisitas adonan mie sehingga mie susah untuk dibentuk. Oleh karena itu pada peneltian ini ditambahkan plasticizer (pemlastis) berupa gliserol.

Pembuatan mie dari tepung gadung dan tepung mocaf menyebabkan warna mie lebih gelap dan tidak menarik. Warna gelap pada tepung gadung disebabkan adanya browning enzimatis pada umbi gadung, browning ini dikarenakan adanya senyawa fenolik. Maka dari itu pada pembuatan mie ditambahkan angkak.

Penelitian ini bertujuan untuk mengetahui kombinasi perlakuan terbaik antara perbandingan tepung gadung : tepung mocaf dan penambahan gliserol yang menghasilkan mie dengan sifat fisik, kimia, dan organoleptik yang terbaik dan disukai oleh konsumen.

\section{BAHAN DAN METODE Bahan}

Bahan yang digunakan untuk pembuatan mie kering yaitu garam, telur ayam, minyak goreng, tepung mocaf merk Ladang Lima, CMC, umbi gadung dari daerah Ponorogo, angkak, dan gliserol. Bahan yang digunakan untuk analisa meliputi aquadest, $\mathrm{AgNO}_{3}, \mathrm{HNO}_{3}$ pekat, KCNS o,o2 N, alkohol 10\%, NaOH 45\%, NaOH 1 N, etanol 95\%, amilosa murni, larutan iod, asam asetat, $\mathrm{K}_{2} \mathrm{SO}_{4}, \mathrm{HgO}, \mathrm{H}_{2} \mathrm{SO}_{4}, \mathrm{H}_{3} \mathrm{BO}_{3}, \mathrm{HCl}$, metanol PA, buffer asetat, DPPH, heksana, dan eter.

\section{Metode Penelitian}

Penelitian ini menggunakan Rancangan Acak Lengkap (RAL) pola faktorial dengan 2 faktor yaitu proporsi tepung gadung:mocaf (80\%:20\%; 70\%:30\%; 60\%:40\%) dan penambahan gliserol (1\%; $2 \% ; 3 \%)$. Data-data yang diperoleh dianalisis menggunakan analisa ragam, bila terdapat perbedaan nyata dilakukan uji duncan (DMRT). Sifat sensoris mie yang dihasilkan diuji dengan metode hedonic scale scoring.

Penelitian ini terdiri dari 2 tahap yaitu tahap pertama adalah pembuatan tepung gadung. Tahap kedua, dilakukan pembuatan mie kering dengan bahan baku tepung gadung dan tepung mocaf dengan penambahan gliserol. Hasil mie kering dilakukan analisa sifat fisikokimia dan organoleptik. Selanjutnya, perlakuan terbaik dilakukan analisis antioksidan, protein, dan warna (colour reader).

\section{1) Proses Pembuatan Tepung Gadung}

Persiapan starter dengan bakteri Lactobacillus plantarum FNCC o047. Umbi gadung dicuci untuk menghilangkan kotoran yang menempel. Kulit umbi gadung dikupas sampai bersih, kemudian ditimbang. Pengecilan ukuran umbi gadung dengan menggunakan mesin penyawut. Air ditambahkan dengan perbandingan 1:1 (b/v). Gadung sawut ditambahkan starter $5 \%$ Lactobacillus plantarum FNCC o047 terhadap volume bahan. Sawut yang telah diinokulasi dengan starter difermentasi selama 3 hari (72 jam) pada suhu kamar. Sawut gadung yang telah difermentasi dicuci dengan air mengalir dan ditiriskan. Sawut gadung dikeringkan menggunakan cabinet dryer dengan suhu $60^{\circ} \mathrm{C}$ selama 17 jam. Sawut gadung yang telah kering digiling menggunakan blender, diayak menggunakan ayakan 80 mesh. Tepung gadung dikemas dengan pengemas kedap udara sebelum digunakan.

\section{2) Proses Pembuatan Mie Kering}

Tepung gadung dan mocaf dicampur sesuai dengan proporsi yang telah ditentukan, kemudian bahan tambahan telur ayam 20 gram (kuning dan putih telur), air 80 ml, garam 3 gram, 
tepung tapioka 12,5 gram, CMC 1,5 gram, dan angkak 3 gram serta gliserol sesuai perlakuan. Pencampuran bahan dilakukan selama 11 menit. Proses ini dilakukan dengan menggunakan noodle maker. Mie yang diperoleh selanjutnya dilakukan perebusan selama \pm 5 menit agar terjadi gelatinisasi pati. Selanjutnya dilakukan pengeringan menggunakan pengering cabinet dengan suhu $\pm 60^{\circ} \mathrm{C}$ selama 8-10 jam.

\section{HASIL DAN PEMBAHASAN}

Pada penelitian ini dilakukan analisa terhadap tepung gadung dan tepung mocaf yaitu kadar sianida (tepung gadung), kadar air, kadar abu, kadar pati, dan kadar amilosa. Hasil analisa tepung gadung dan tepung mocaf dapat dilihat pada Tabel 1.

Tabel 1. Hasil analisa tepung gadung dan tepung mocaf

\begin{tabular}{|c|c|c|c|c|}
\hline \multirow[t]{2}{*}{ Parameter } & \multicolumn{2}{|c|}{ Tepung Gadung } & \multicolumn{2}{|c|}{ Tepung Mocaf } \\
\hline & Analisa & Literatur & Analisa & Literatur \\
\hline Kadar Air (\%) & 10,01 & $12,71^{\mathrm{a}}$ & 7,61 & $6,85^{c}$ \\
\hline Kadar Abu (\%) & 0,58 & $3,00^{a}$ & 0,94 & $0,99^{c}$ \\
\hline Kadar Pati (\%) & 61,19 & $65, \mathrm{oO}^{\mathrm{b}}$ & 73,49 & $76,80^{c}$ \\
\hline Kadar Amilosa (\%) & 9,92 & $31,40^{\mathrm{a}}$ & 26,79 & $20,13^{c}$ \\
\hline Kadar Amilopektin (\%) & 51,27 & - & 46,70 & - \\
\hline Kadar Sianida (ppm) & 13,48 & $19,95^{\mathrm{b}}$ & - & - \\
\hline
\end{tabular}

Sumber: a)Rosmeri dan Monica, 2013 b)Syafi'i dkk., 2009 c)Khotimah, 2016

\section{Kadar Air Mie Kering}

Hasil pengamatan terhadap kadar air mie kering dari tepung gadung dan tepung mocaf dengan penambahan gliserol berkisar antara 7,15-10,59\%. Kadar air mie kering dapat dilihat pada Gambar 1. Pada Gambar 1 menunjukkan bahwa semakin rendah proporsi tepung gadung dan semakin tinggi proporsi tepung mocaf serta semakin tinggi penambahan gliserol menyebabkan kadar air mie kering meningkat. Hal ini disebabkan karena tepung mocaf mengandung komponen penyusun terbesar yaitu pati yang bersifat hidrofilik. Winarno (2004) menambahkan bahwa peningkatan kadar air disebabkan pati bersifat hidrofilik mempunyai daya tarik terhadap air dan mempunyai gugus hidrofilik yang membentuk ikatan hidrogen dengan molekul air.

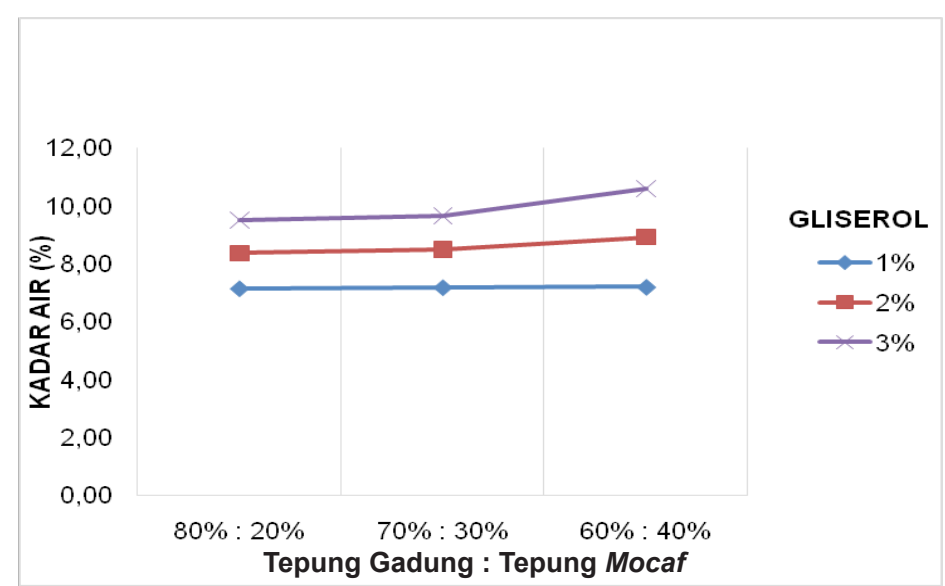

Gambar 1. Kadar air mie kering pada perlakuan proporsi tepung gadung : tepung mocaf dengan penambahan gliserol. 
Semakin tinggi penambahan gliserol maka kadar air semakin meningkat. Hal ini dikarenakan gliserol memiliki kemampuan sebagai humektan yang dapat mengikat air sehingga pada saat pengeringan air sulit menguap. Semakin tinggi penambahan gliserol akan meningkatkan sifat kohesif (pati) antar molekul dari gliserol, dan jumlah air yang terikat dengan hidrokoloid (pati) akan mengalami kenaikan yang menyebabkan kadar airnya semakin tinggi. Menurut Fennema (1996) gliserol dapat mengikat air dalam jumlah besar sehingga air berada di luar granula menjadi berada didalam granula dan tidak bebas lagi sehingga dapat meningkatkan kadar air mie kering.

\section{Kadar Pati Mie Kering}

Diketahui bahwa perlakuan proporsi tepung gadung:tepung mocaf dan penambahan gliserol tidak terdapat interaksi yang nyata ( $\mathrm{p} \leq 0,05)$ terhadap kadar pati mie kering, tetapi proporsi tepung gadung:tepung mocaf berpengaruh nyata terhadap kadar pati mie kering, sedangkan penambahan gliserol tidak berpengaruh nyata terhadap kadar pati mie kering. Nilai rata-rata kadar pati mie kering dapat dilihat pada tabel 2 dan 3.

Tabel 2. Nilai rata-rata Kadar Pati Mie Kering

\begin{tabular}{c|c|c}
\hline $\begin{array}{c}\text { Proporsi Tepung Gadung : Tepung } \\
\text { Mocaf (\%) }\end{array}$ & $\begin{array}{c}\text { Rata-rata Kadar Pati } \\
(\%)\end{array}$ & Notasi \\
\hline $80: 20$ & 65,62 & $\mathrm{a}$ \\
$70: 30$ & 67,31 & $\mathrm{~b}$ \\
$60: 40$ & 69,07 & $\mathrm{c}$ \\
\hline
\end{tabular}

Semakin rendah proporsi tepung gadung dan semakin tinggi proporsi tepung mocaf maka kadar pati semakin meningkat. Hal ini disebabkan karena kandungan pati tepung mocaf lebih tinggi dibandingkan dengan tepung gadung yaitu $73,49 \%$, sehingga semakin tinggi proporsi tepung mocaf dalam pembuatan mie kering secara langsung akan meningkatkan kadar patinya.

Tabel 3. Nilai rata-rata Kadar Pati Mie Kering perlakuan penambahan gliserol.

\begin{tabular}{c|c|c}
\hline Penambahan Gliserol (\%) & Rata-rata Kadar Pati (\%) & Notasi \\
\hline 1 & 66,97 & $\mathrm{a}$ \\
2 & 67,37 & $\mathrm{a}$ \\
3 & 67,67 & $\mathrm{a}$ \\
\hline${ }^{*}$ ) angka yang didampingi huruf yang berbeda menunjukkan perbedaan yang nyata ( $\left.\mathrm{p} \leq \mathrm{0}, 05\right)$.
\end{tabular}

Penambahan gliserol tidak menunjukkan pengaruh nyata terhadap kadar pati yang dihasilkan. Hal ini dikarenakan gliserol merupakan suatu plasticizer yang termasuk alkohol (poliol) dan di dalam gliserol tidak terdapat pati sehingga tidak mempengaruhi kadar pati. Hal ini didukung oleh pendapat (Huri dan Nisa, 2014) bahwa gliserol termasuk jenis plasticizer dan pendapat (Adnan, 1982) bahwa gliserol merupakan humektan yang termasuk golongan poliol.

\section{Kadar Amilosa}

Diketahui bahwa perlakuan proporsi tepung gadung:tepung mocaf dan penambahan gliserol tidak terdapat interaksi yang nyata ( $\mathrm{p} \leq 0,05)$ terhadap kadar amilosa mie kering, tetapi proporsi tepung gadung:tepung mocaf berpengaruh nyata terhadap kadar amilosa mie kering, sedangkan penambahan gliserol tidak berpengaruh nyata terhadap kadar amilosa mie kering. Nilai rata-rata kadar pati mie kering dapat dilihat pada tabel 4 dan 5 . 
Tabel 4. Nilai rata-rata Kadar Amilosa Mie Kering

\begin{tabular}{c|c|c}
\hline $\begin{array}{c}\text { Proporsi Tepung Gadung:Tepung Mocaf } \\
(\%)\end{array}$ & $\begin{array}{c}\text { Rata-rata Kadar } \\
\text { Amilosa }(\%)\end{array}$ & Notasi \\
\hline $80: 20$ & 9,77 & a \\
$70: 30$ & 11,33 & bc \\
$60: 40$ & 13,09 & bc \\
\hline
\end{tabular}

*) angka yang didampingi huruf yang berbeda menunjukkan berbeda nyata $(\mathrm{p}<0,05)$.

Tabel 5. Nilai rata-rata Kadar Amilosa Mie Kering perlakuan penambahan gliserol.

\begin{tabular}{c|c|c}
\hline Penambahan Gliserol (\%) & Rata-rata Kadar Amilosa (\%) & Notasi \\
\hline 1 & 10,99 & $\mathrm{a}$ \\
2 & 11,27 & $\mathrm{a}$ \\
3 & 11,70 & $\mathrm{a}$ \\
\hline
\end{tabular}

*) angka yang didampingi huruf yang berbeda menunjukkan perbedaan yang nyata ( $\leq \leq 0,05)$.

Semakin rendah proporsi tepung gadung dan semakin tinggi proporsi tepung mocaf maka kadar amilosa semakin meningkat. Hal ini disebabkan karena kandungan amilosa tepung mocaf lebih tinggi dibandingkan dengan tepung gadung yaitu $26,79 \%$. Semakin tinggi proporsi tepung mocaf kadar amilosa semakin meningkat. Penambahan gliserol tidak menunjukkan pengaruh nyata terhadap kadar amilosa yang dihasilkan. Hal ini dikarenakan gliserol merupakan suatu plasticizer yang merupakan golongan alkohol (poliol) dan didalam gliserol tidak terdapat amilosa sehingga tidak mempengaruhi kadar amilosa. Hal ini didukung oleh pendapat Goudung (2004) dalam Mahendra (2013) bahwa gliserol merupakan poliol netral. Gliserol dapat larut sempurna dalam air dan alkohol. Senyawa poliol banyak digunakan sebagai pemlastis.

\section{Daya Patah Mie Kering}

Hasil pengamatan terhadap daya patah mie kering dari proporsi tepung gadung dan tepung mocaf dengan penambahan gliserol berkisar antara 8,69\%-12,70\%. Nilai daya patah mie kering dapat dilihat pada Gambar 2.

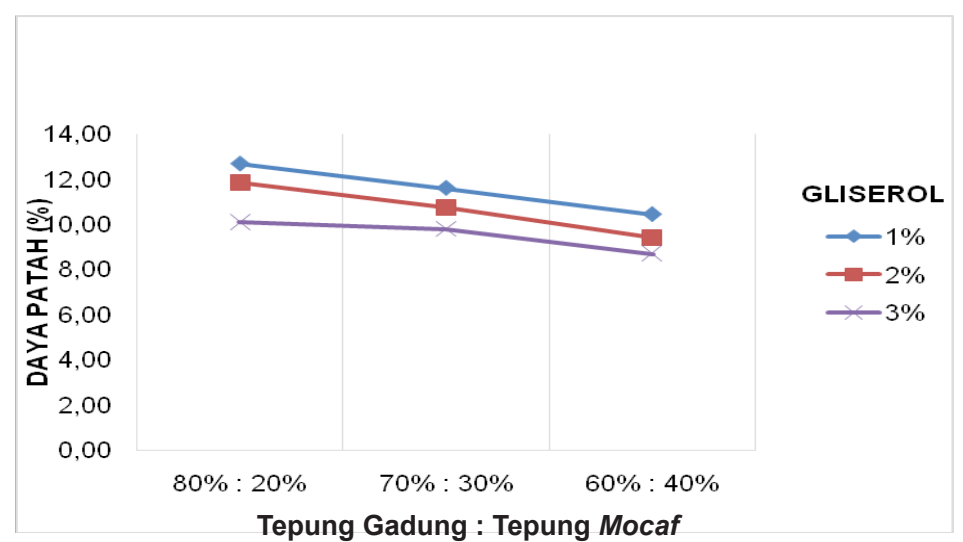

Gambar 2. Nilai daya patah mie kering dari perlakuan proporsi tepung gadung : tepung mocaf dengan penambahan gliserol

Gambar 2 menunjukkan bahwa dengan semakin rendah proporsi tepung gadung dan semakin tinggi proporsi tepung mocaf serta semakin tinggi penambahan gliserol menyebabkan daya patah mie kering menurun. Hal ini disebabkan protein bersifat mengikat air, semakin rendah tepung gadung kemampuan mengikat air semakin rendah, dan pembentukan gel menjadi tidak kokoh sehingga mie mudah patah. Hal ini didukung oleh pendapat Widiatmoko dan Estiasih (2015), bahwa protein berfungsi sebagai bahan pengental dan membentuk tekstur yang kenyal dan kokoh pada mie kering ubi jalar ungu, semakin tinggi penambahan gliserol maka daya patah semakin menurun. Hal ini dikarenakan konsentrasi 
gliserol telah melebihi batas maksimal yang menyebabkan molekul gliserol yang berlebih berada dalam fase tersendiri di luar fase polimer dan gaya intermolekul antar rantai polimer pati semakin tinggi, dimana jumlah plasticizer berlebihan dan tidak berfungsi sebagaimana mestinya.

\section{Elastisitas Mie Basah}

Hasil pengamatan terhadap elastisitas mie kering dari proporsi tepung gadung dan tepung mocaf dengan penambahan gliserol berkisar antara 45,83-22,80\%. Nilai Elastisitas mie basah dapat dilihat pada Gambar 3.

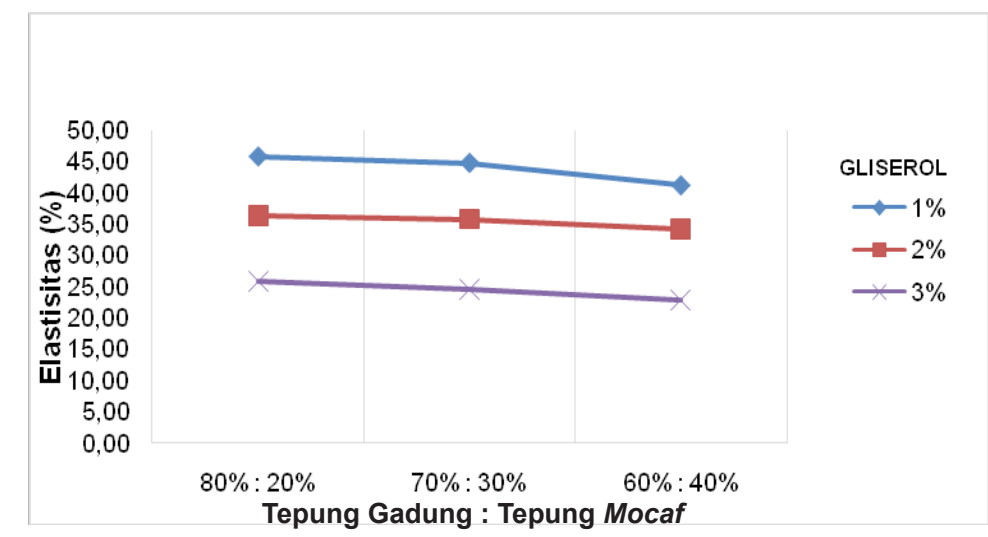

Gambar 3. Nilai elastisitas mie basah pada perlakuan proporsi tepung gadung: tepung mocaf dengan penambahan gliserol

Gambar 3 menunjukkan bahwa semakin rendah proporsi tepung gadung dan semakin tinggi proporsi tepung mocaf serta semakin tinggi penambahan gliserol menyebabkan elastisitas mie basah menurun. Semakin rendah proporsi tepung gadung maka elastisitas mie menurun. Hal ini disebabkan seiring menurunnya proporsi tepung gadung menyebabkan kandungan pati (amilopektin) semakin menurun sehingga elastisitas menurun. Hal ini didukung oleh pendapat Boediono (2012) menyatakan bahwa amilopektin dapat memberikan sifat lengket/elastis pada mie yang dihasilkan, sehingga mie tidak mudah putus atau patah. Semakin tinggi penambahan gliserol maka elastisitas semakin menurun. Hal ini dikarenakan konsentrasi gliserol telah melebihi batas maksimal sehingga molekulmolekul plasticizer yang berlebih berada dalam fase tersendiri di luar fase polimer dan gaya intermolekul antar rantai pada pati semakin tinggi, maka semakin tinggi penambahan gliserol elastisitas semakin menurun, dimana jumlah plasticizer melebihi batas dan akan terjadi sistem heterogen dan elastisitas yang terjadi akan tidak semestinya.

\section{Daya Rehidrasi}

Hasil pengamatan terhadap elastisitas mie kering akibat proporsi tepung gadung dan tepung mocaf dengan penambahan gliserol berkisar antara 34,42-51,33\%. Nilai daya rehidrasi mie basah dapat dilihat pada Gambar 4. 


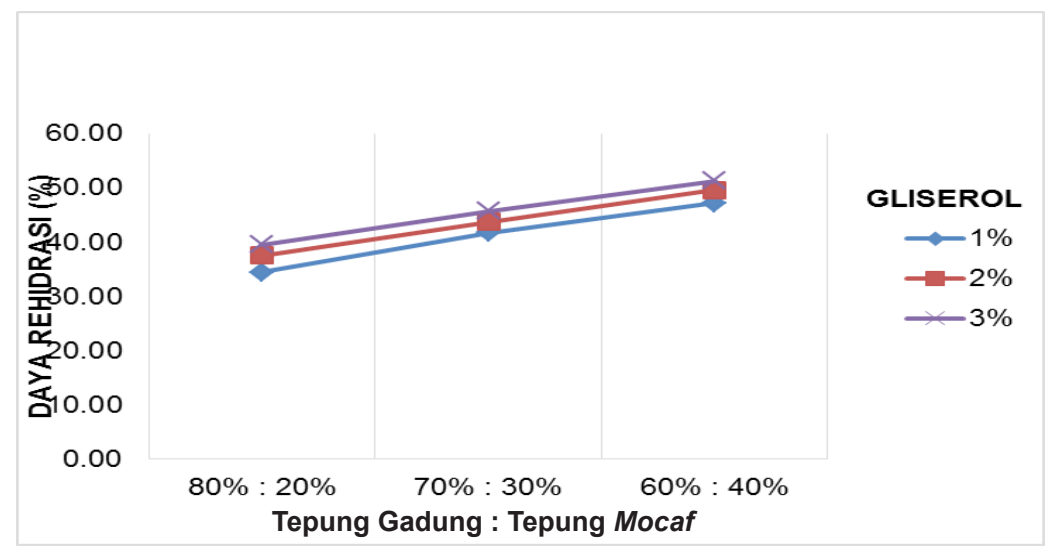

Gambar 4. Daya rehidrasi mie kering pada perlakuan proporsi tepung gadung:tepung mocaf dengan penambahan gliserol

Gambar 4 menunjukkan bahwa dengan semakin rendah proporsi tepung gadung dan semakin tinggi proporsi tepung mocaf serta semakin tinggi penambahan gliserol menyebabkan daya rehidrasi mie kering meningkat. Hal ini dikarenakan tepung gadung mempunyai kadar pati lebih rendah $(62,19 \%)$ dengan amilosa sebesar 9,92\% daripada tepung mocaf $(73,49 \%)$ dengan amilosa sebesar $26,79 \%$ sehingga kadar pati (amilosa) dan kemampuan menyerap airnya lebih besar. Menurut Wirakartakusumah et al. (1986) apabila kadar amilosa tinggi, maka pati cenderung menyerap air lebih banyak. Semakin tinggi penambahan gliserol maka daya rehidrasi semakin meningkat. Hal ini disebabkan setiap molekul gliserol mengandung 3 gugus molekul hidroksil sehingga mudah berikatan dengan air dan pati.

\section{Cooking loss mie}

Hasil pengamatan terhadap elastisitas mie kering dari proporsi tepung gadung dan tepung mocaf dengan penambahan gliserol berkisar antara 2,47-7,78\%. Nilai cooking loss mie basah dapat dilihat pada Gambar 5. Gambar 5 menunjukkan bahwa dengan semakin rendah proporsi tepung gadung dan semakin tinggi proporsi tepung mocaf serta semakin tinggi penambahan gliserol menyebabkan cooking loss mie kering meningkat. Perbedaan cooking loss disebabkan oleh kandungan amilosa pada tepung. Hal ini juga dikarenakan mocaf $(26,79 \%)$ mempunyai kadar amilosa lebih tinggi dari pada tepung gadung (9,92\%). Semakin tinggi air yang diserap maka semakin banyak padatan yang hilang yang disebabkan terlepasnya pati (amilosa) pada untaian mie ke dalam air rebusan mie. Hal ini didukung oleh pendapat Saniati dkk, (2013) bahwa cooking loos yang tinggi disebabkan oleh kurang optimumnya kemampuan matrik pati tergelatinisasi untuk mengikat pati yang tidak tergelatinisasi.

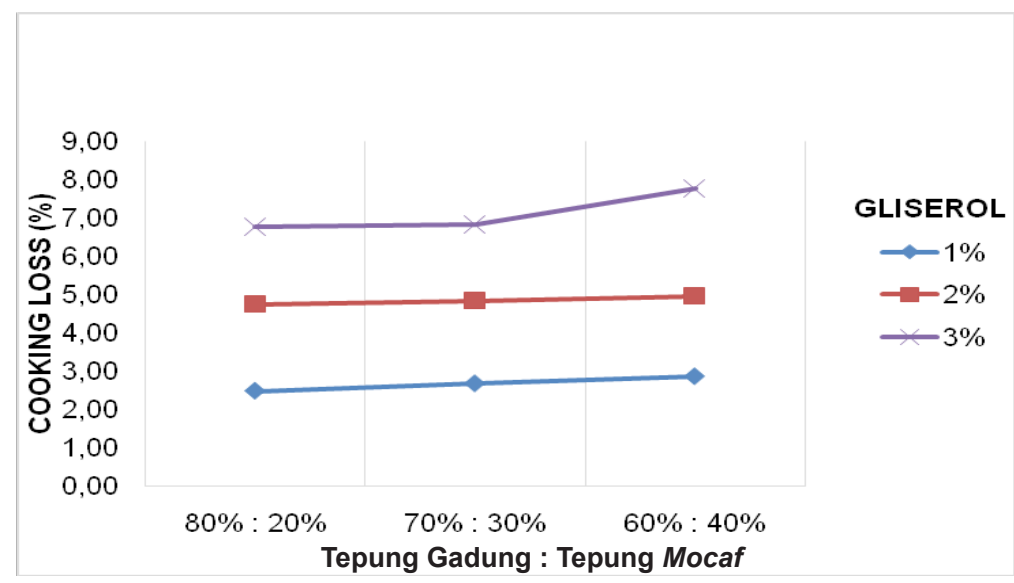

Gambar 5. Cooking loss mie kering pada perlakuan proporsi tepung gadung:tepung mocaf dengan penambahan gliserol terhadap. 
Gambar 5 menunjukkan bahwa semakin tinggi penambahan gliserol maka cooking loss semakin meningkat. Hal ini disebabkan gliserol adalah bahan yang bersifat hidrofilik. Dengan adanya air yang terlalu banyak dapat menyebabkan nilai cooking loss menjadi tinggi. Hal ini didukung oleh pendapat Fu (2007), bahwa terlalu banyak air juga tidak baik karena mengakibatkan adonan lengket dan susah dibentuk.

\section{Hasil Uji Sensoris}

Tingkat kesukaan panelis terhadap warna mie kering matang didapatkan nilai rata-rata berkisar 2,45-3,90 (tidak suka - agak suka). Perlakuan proporsi tepung gadung 60\%:tepung mocaf $40 \%$ dan penambahan gliserol $1 \%$ menghasilkan warna mie kering matang dengan tingkat kesukaan tertinggi. Tingkat kesukaan panelis terhadap rasa mie kering matang didapatkan nilai rata-rata berkisar 2,90 - 3,00 (tidak suka - agak suka). Perlakuan proporsi tepung gadung $70 \%$ : tepung mocaf 30\% dan penambahan gliserol $1 \%$ menghasilkan rasa mie kering matang dengan tingkat kesukaan tertinggi. Tingkat kesukaan panelis terhadap tekstur mie kering matang didapatkan nilai ratarata berkisar 2,55-3,70 (tidak suka - agak suka). Perlakuan proporsi tepung gadung 60\%:tepung mocaf $40 \%$ dan penambahan gliserol $1 \%$ menghasilkan tekstur mie kering matang dengan tingkat kesukaan tertinggi. Tingkat kesukaan panelis terhadap aroma mie kering matang didapatkan nilai rata-rata berkisar 2,953,6o (tidak suka - agak suka). Perlakuan proporsi tepung gadung 6o\%:tepung mocaf 40\% dan penambahan gliserol $1 \%$ menghasilkan aroma mie kering matang dengan tingkat kesukaan tertinggi.

\section{KESIMPULAN}

Hasil perlakuan terbaik adalah proporsi tepung gadung:tepung mocaf 60\%:40\% dan penambahan gliserol 1\% yang menghasilkan mie dengan karakteristik kadar air 7,20\%, kadar pati 68,59\%, kadar amilosa $12,55 \%$, daya patah $10,44 \%$, daya rehidrasi $47,23 \%$, elastisitas mie basah $41,17 \%$ dan cooking loss 2,85 , serta uji sensoris nilai rata-rata warna 3,90 (agak suka), rasa 3,75 (agak suka), tekstur 3,70 (agak suka), dan aroma 3,6o (agak suka). Hasil perlakuan terbaik dianalisa kadar protein adalah 3,02\%, warna L 48,6; $\mathrm{a}^{*} 24,4$; $\mathrm{b}^{*} 14,2$ dan aktivitas antioksidan 385,00 (mg/ $\mathrm{ml})$.

\section{DAFTAR PUSTAKA}

Astawan, M. 2008. Membuat Mi dan Bihun. Cetakan XI. Jakarta: Penebar Swadaya.

Boediono, M. P. A. D. R. 2012. Pemisahan dan Pencirian Amilosa dan Amilopektin dari Pati Jagung dan Pati Kentang pada Berbagai Suhu. Skripsi. FMIPA. Institut Pertanian Bogor.

Fennema, O. R. 1996. Food Chemistry, third edition. Marcel Dekker, Inc. New York.

Harijono, Sari, T. A., dan Martati, E. 2008. Detoksifikasi Umbi Gadung (Dioscorea hispida Dennst) dengan Pemanasan Terbatas dalam Pengolahan Tepung Gadung. Jurnal Teknologi Pertanian 9 (2): 75-82.

Huri, D. dan Nisa, F. C. 2014. Pengaruh Konsentrasi Gliserol dan Ekstrak Ampas Kulit Apel terhadap Karakteristik Fisik dan Kimia Edible Film. Jurnal Pangan dan Agroindustri 2(4): 29-40.

Khotimah, H. K. 2016. "Kajian Substitusi Tepung Mocaf dan Karagenan Terhadap Kualitas Beras Analog Dari Umbi Gembili (Dioscorea esculenta L.)". Skripsi. Jurusan Teknologi Pangan. Universitas Pembangunan Nasional "Veteran" Jawa Timur. Surabaya.

Mahendra, A. 2013. Aktivitas Antimikroba Sediaan Biomaterial Selulosa Bakteri Dari Limbah Ketela Rambat (Ipomoea batatas Poir) Dengan Penambahan Kitosan Terhadap Staphylococcus aureus. Skripsi. Fakultas Farmasi Universitas Sanata Darma. Yogyakarta.

Rosmeri, V. R., dan Monica, B. N. 2013. Pemanfaatan Tepung Gadung (Dioscorea hispida Dennts) dan Tepung Mocaf (Modified Cassava Flour) sebagai Bahan Substitusi dalam Pembuatan Mie Basah, Mie Kering, dan Mie Instan. Universitas 
Diponegoro: Jurnal Teknologi Kimia dan Industri Vol 2, No 2, Halaman 246-256.

Salim, Amil. 2011. Mengolah Tepung Singkong Menjadi Tepung Mocaf. Yogyakarta: Lily Publisher.

Saniati, N. D., Nurdjanah, S., Susilawati., dan Musita, N. 2013. Sifat Organoleptik Mie Berbahan Dasar Tepung Jagung (Zea mays L.) Ternikstamalisasi. Jurnal Teknologi Industri dan Hasil Pertanian 18(2): 114-122.

Sasongko, P. 2009. Detoksifikasi Umbi Gadung (Discorea hispida Dennts) Melalui Proses Fermentasi Menggunakan Kapang Mucor sp. . Jurnal Teknologi Pertanian 10 (3): 205-215.

Syafi'I, I., Harijono., dan Eryana, M. 2009. Detoksifikasi Umbi Gadung (Dioscorea hispida Dennts) dengan Pemanasan dan Pengasaman Pada Pembuatan Tepung. Jurnal Teknologi Pertanian 1(10): 62-68.

Subagio, A. 2007. Industrialisasi Modified Cassava Flour (MOCAF) sebagai Bahan Baku Industri Pangan untuk Menunjang Diversifikasi Pangan Pokok Nasional.
Jember : Fakultas Teknologi Pertanian, Universitas Jember.

Widiatmoko, R. B. Dan Estiasih, T. 2015. Karakteristik Fisikokimia dan Organoleptik Mie Kering Berbasis Tepung Ubi Jalar Ungu pada Berbagai Tingkat Penambahan Gluten. Jurnal PangandanAgroindustriz(4)1386-1392. Wirakartakusumah, M. A., Apriantono, M. S., Ma'arif, Suliantari, Muchtadi, D., dan Otaka, K. 1986. Isolation and Caracterization pf Sago Starch And Its Utilation for Production of Liquid Sugar, dalam FAO (ed.), The Development of The Sago Palm and Its Product. Report of the FAO/BPP Teknologi Consultation . Jakarta.

Winarno, F. G. 2004. Kimia Pangan dan Gizi. Cetakan XI. Jakarta: PT. Gramedia Utama Pustaka..

Yeni, D. S.P. 2012. Tepung Mocaf Alternatif Pengganti Terigu. Balai Pendidikan dan Pelatihan Daerah Provinsi Jawa Barat. 